\title{
Pop-Goes-The-Library! Using a Pop-Up Library to Reach STEM Students
}

\section{Ms. Joanne Dera, New Jersey Institute of Technology}

Joanne Dera is the Science and Engineering Librarian at the New Jersey Institute of Technology. She is the liaison librarian for the following departments: Chemistry \& Environmental Science, Chemical \& Materials Engineering, Civil \& Environmental Engineering, and Physics.

\section{Dr. Davida Scharf, New Jersey Institute of Technology}

Davida Scharf has a B.A. from Barnard College in Art and Architectural History, an MLS from Columbia University, and a PhD from the Rutgers University School of Communication and Information in the area of educational assessment and information literacy. She is currently Director of Reference and Instruction at the New Jersey Institute of Technology in Newark, NJ.

\section{Mr. Joseph J. Mercuri, New Jersey Institute of Technology}

Joseph Mercuri is a Technical Reference Librarian at New Jersey Institute of Technology (NJIT). He is the library liaison for the Biological Sciences, Biomedical Engineering, Computer Science, Informatics, Information Technology, and Mathematical Sciences departments.

\section{Mr. Raymond Patrick Vasquez, New Jersey Institute of Technology}

Raymond Vasquez is the Research and User Services Librarian at the New Jersey Institute of Technology. $\mathrm{He}$ is also the liaison librarian to the Electrical and Computer Engineering, Engineering Technology and Mechanical and Computer Engineering academic departments. 


\section{Pop-Goes-The-Library! Using a Pop-Up Library to Innovate Outreach to Science and Engineering Students}

A Pop-Up Library program started at the New Jersey Institute of Technology as an innovative means of outreach and education for our science and engineering students to increase library visibility by promoting and providing library services in other student-centered areas of study. Providing new and unique opportunities tailored for the science and engineering students is of particular interest, especially for undergraduates who may not have the need to interact with library resources or liaison librarians until farther along in their undergraduate or graduate studies due to other course requirements mostly consisting of engineering fundamentals, and focus in laboratory and design assignments. The benefits of taking the library to the students include providing opportunities for the library staff to meet more students and faculty, promote library research resources, and create follow-up appointments for one-on-one research assistance. This paper discusses the implementation details of the program, such as, determining the best locations for the pop-up library, the marketing and publicity of each pop-up, the types of resources and services that were highlighted, and the ways library staff conducted each operation. The effectiveness of the pop-up library program was assessed by evaluating number and type of each interaction at each session. Promoting and providing library reference services through innovative ways allow interaction with science and engineering students who may not primarily seek the library as a means of support and assistance.

\section{Introduction}

The New Jersey Institute of Technology (NJIT) is a public polytechnic research university which offers over 125 degree programs predominantly in STEM disciplines. With only four reference/liaison librarians serving more than 11,000 students and 500 faculty, we suspected that many users were unaware of the full potential of the library and librarians to assist them with their research. In the Fall 2017 semester, an extensive, campus-wide student library satisfaction survey was conducted which confirmed some of our suspicions.

Surveys were emailed to 7,806 undergraduates and 2,918 graduate students. 1,841 responses were received for an overall response rate of $17 \%$. More than $80 \%$ of respondents who used the library in Fall 2017 were satisfied or very satisfied with the library and its services.

However, when asked about whether they knew about our reference and departmental liaison services the responses were tellingly different. Less than $30 \%$ of undergraduate and graduate students knew that most of our resources were available online, less than $28 \%$ were aware of our self-help tutorials and Libguides, and less than 31\% were aware of our departmental liaison program. Only $18 \%$ of the respondents said that they got help from a librarian when citing 
sources or doing research BUT fewer than $25 \%$ of the undergraduates and graduate students could recognize a scholarly article from a list of different types of citations given in the survey.

In the Spring 2018 semester, a library satisfaction survey for faculty was distributed. 544 faculty were requested to complete the survey, 28 responses were received at a response rate of $5 \%$. Although the response rate was low, some responses were interesting and caused our liaison librarians to think further on how to better market the library. Below are some examples to one of the survey questions:

How do you think a librarian could best contribute to the performance of your students?

- Better outreach to faculty and students so students are aware of the many wonderful services available to them.

- Probably a lot but students don't utilize librarians as resources.

- Intro Physics students don't do reports.

- I don't utilize the amazing resources at the library enough - would be wonderful to be more knowledgeable about what is available.

- Most students just consider the library as a convenient and quiet place in which to study, and have little interaction with the librarians or the books.

$81 \%$ of the students at NJIT are in STEM degrees/programs. Most of these students have limited need to seek out reference assistance due to curriculum requirements that focus on scientific fundamentals and practical applications. However, ABET, the Accreditation Board for Engineering and Technology, Criteria for Accrediting Engineering Programs is driving some of the science and engineering departments to see more need for information literacy instruction. ABET General Criterion 3(g), (h), (i), and (j) - Student Outcomes, requires "an ability to communicate effectively", "the broad education necessary to understand the impact of engineering solutions in a global, economic, environmental, and societal context", "a recognition of the need for, and an ability to engage in life-long learning", and "a knowledge of contemporary issues' [1]. To meet this criteria, more writing assignments are being included in NJIT fundamental science and engineering courses, such as, literature reviews, technical report writing, scientific article summaries, etc., Even though assignments requiring information literacy skills are being added, students' perception that they can do it on their own without the intervention of a librarian is prevalent based on the student survey results.

In order to address the need to increase the library's visibility and to promote our electronic resources and liaison services, reference librarians decided to use the pop-up library concept as a way to market to STEM students. 


\section{Literature Review}

Engineering students' perception of library use begins at the undergraduate level, where foundational courses involve learning scientific theory and solving problems that do not require library use [2]. Even though most colleges require humanities and language arts courses for undergraduates in science and engineering programs, these students typically seek help differently than those in liberal arts majors. They typically don't use the library beyond its traditional purpose of a place to study. They may be unaware of library services and resources and are not known to ask for help in using library resources or completing research assignments [2]. Their confidence and competence in being technologically savvy makes them more reluctant to fully utilize library services [3].

Carroll, et. al. [4] hypothesized that engineering and science students low usage of the library doesn't reflect on their lack of information needs, but that the library doesn't integrate easily with engineering instructional programs. The authors also considered that even though information literacy instruction has been integrated into some science and engineering curriculums, the limited interaction of academic librarians with students and/or faculty isn't enough to transform their information seeking behavior. As noted by Gross [5], “...not all colleges and universities require that students receive information literacy instruction". Fransen [6] determined that even though undergraduate students have opportunities and reasons to use library resources for electives, that need is not apparent in science and engineering courses. In addition to data collected to evaluate library transactions, results showed that science and engineering undergraduate students use the library less than students in other majors [6]. Even for students that do receive some information literacy instruction within their courses, "the fact remains that students who are unaware of a deficit in their information literacy skills are unlikely to seek skill remediation on their own or to engage with instruction when forced to take it" [5].

The underuse of library resources and services for science and engineering students results from three major reasons, lack of need in coursework, misperception of competence in information seeking abilities, and lack of awareness of the library's resources and services [2] [5] [6]. We, as liaison librarians, continually seek to tackle each one of these issues in many ways. Establishing relationships with faculty to incorporate or embed information literacy in coursework is a primary goal. The inclusion of assignments that require information literacy skills and hands-on classroom instruction by liaison librarians will also introduce the reality that their information-seeking skills may not be as competent as they thought and eliminate the misperception that they do not need the library to succeed. To increase usage of the library's resources and services, we also need better promotion of our resources and services to the science and engineering students that may not be coming into our physical or virtual library spaces. 
Empey and Black state "Marketing can and does serve many purposes. Not only can it be instrumental in raising the profile of the academic library, but marketing also serves to educate and inform users about the important research function the library provides" [7] Also, in order to highlight the library's value to its student community it first needs to make students aware of what it has to offer [8]. Promoting our library services and resources is not a new concept. Many traditional marketing methods have been used for promotion, such as, print flyers, website flyers, email newsletters, video slideshows, and presentations at graduate seminars and faculty meetings. However, based on the student survey results, we wanted to try a more innovative method.

In recent years, pop-up retail stores have become very popular, especially around the holidays, to create buzz or to generate excitement or spontaneous purchases of popular items. To draw on that trend, many public and academic libraries have incorporated pop-up libraries to promote resources and services and reach populations that are underserved. Pop-up libraries are a simple, low-cost, way to positively promote the library's image, and expand reach to the community [9]. At the University of Birmingham, a temporary library program was set up to extend the reach of library services beyond current users and to promote services and resources. They also sought to provide opportunities for students to interact with library staff in an informal setting and for staff to learn more about what students thought about using the library [10]. At the University of Montana, pop-up libraries were used as an extension of previous outreach efforts by trying to meet the students at their point of need [11]. The University of Texas at San Antonio devised their Direct-2-U Reference to provide reference services to students in other spaces on campus, giving them the opportunity for personalized help without having to go to the library [12]. North Carolina State University created their pop-up library program called "Ask Us Here" by specifically targeting engineering students in the lobbies and atriums of their departmental buildings [3].

Pop-up library research showed different outcomes resulting from the librarians' efforts to bring the library to the students. Some perceived the interactions valuable enough to continue the service indefinitely. The Direct-2-U Reference program had strong enough results to make the program a regular part of their librarians' duties [12]. Some had mixed results and feelings about the program. The University of Montana's program determined that the number of reference interactions was not what they had hoped for, however, the publicity generated to promote the library's resources was worth the effort. Others, decided that the program did not produce enough positive results for the time it took to facilitate. At Indiana State University, the low-number of interactions was not perceived as valuable use of the librarians' time [13]. 


\section{Methodology}

The Robert W. Van Houten Library is NJIT's main university library in which there are four reference librarians that also serve as departmental liaisons who provide information literacy instruction and research assistance for the students and faculty. The two primary goals of the pop-up library program at NJIT were to increase the library's visibility and to promote resources and liaison services, especially to science and engineering students. The following methodology outlines the factors that were considered when planning the pop-up library: location, timing, marketing, set-up, and approach.

Location: Throughout the semester, pop-ups were held at the Campus Center and in science and engineering department building lobbies and mixed use study spaces. Prior to the pop-ups, several locations were assessed based on the following questions. Was there an existing table that can be used? What was the atmosphere like? Were students quietly studying? Was it a social study space? As Strothmann and Antell [14] discussed, a good location consists of a high-traffic area with a large number of potential users but also quiet enough to hold meaningful conversation. The most useful setting also requires an academic setting where students are in a point of need for research help [14].

Timing: We tried pop-ups at different times of the day, late morning, lunchtime, early afternoon. We also tried pop-ups during Common Hours, which are twice a week for about 2 hours when there are no classes scheduled. The length of the pop-up was varied to determine what was the most worthwhile for the librarians' time, as well as the students. Most were approximately one hour long.

Marketing: To market the library's services we wanted to personalize the liaison librarian's role for each particular department. This was done through the use of a tri-fold poster board at each pop-up that displayed the liaison librarians' photos, assigned departments, and the various ways to contact them. An image of the display can be seen in Figure 1. The display also highlighted specific resources available to students with promotional flyers, such as our free subscription to the New York Times and subject-specific LibGuides and databases. QR codes were generated and posted on each flyer for students to access the resources we were promoting. We created "tickets", 4 inch x 2 1/4 inch slips of paper designed to highlight specific resources, services, and liaison librarian's contact information. These tickets were handed out at each pop-up location and were readily taken by students and faculty. Promotional tickets for each of the following resources were created: New York Times online subscription, specific science and engineering subject LibGuides, "Understanding Citations" LibGuide, the SciFinder Scholar database, "How to Determine Fake News" LibGuide, as well as, other promotion of other science and engineering related databases. An example of these tickets is shown in Figure 2. 


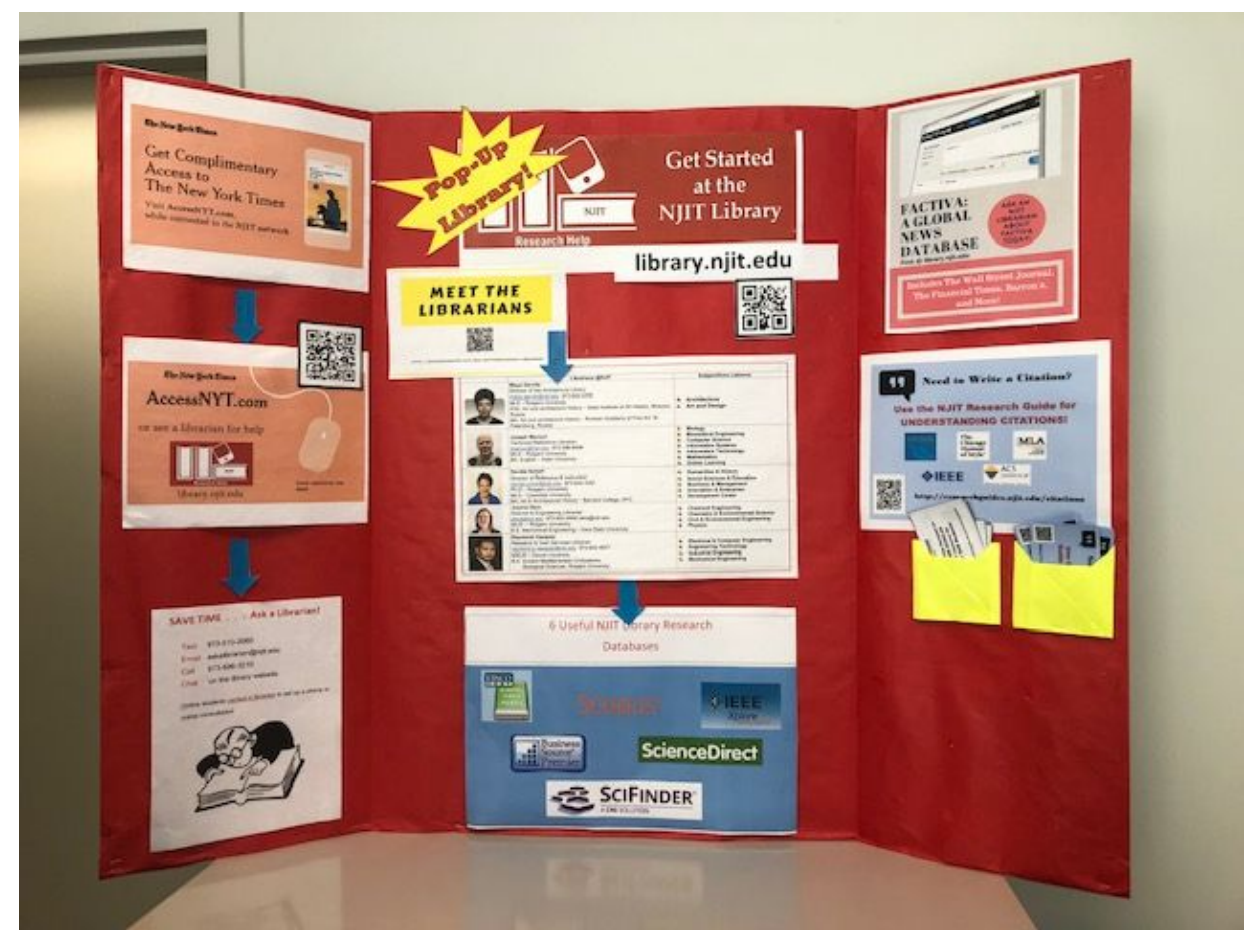

Figure 1: Pop-up Tri Fold Display

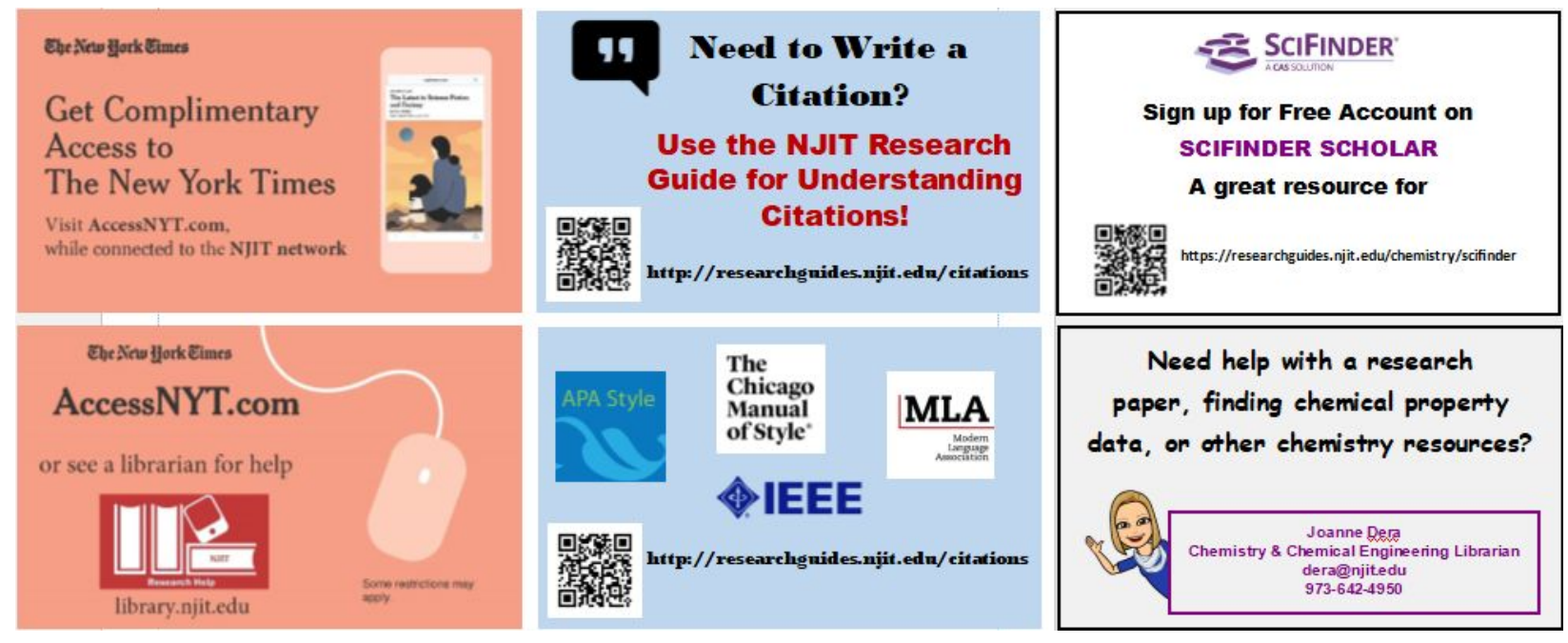

Figure 2: Double-Sided Promotional Tickets

Set-up: At each individual site, we either used an existing table at the location or brought along a folded card table, tablecloth, the tri-fold poster board with marketing materials, the promotional tickets, candy, and a laptop for on-the-spot reference questions. The candy usually enticed students to stop by and talk with us. 
Approach: We tried different approaches during the pop-up: a direct approach - actively handing out tickets and introducing ourselves to every student/faculty in the area, a passive approach letting students/faculty show interest in the pop-up first, and a hands-off approach - leaving the display set-up alone. Students have been found to need a determinate amount of space to observe prior to actually engaging in a situation where they do not know yet if they have enough interest [14]. We found that the ideal approach is situational, determined by location and atmosphere within that location, i.e. quiet study, bustling social area, etc.

At pop-ups that we used the direct approach, actively interacting with students, we recorded any meaningful conversations using the laptop that we brought to each pop-up. We would record the type of conversation, such as, answering a reference question, discussing future collaboration with a faculty member, showing a student or faculty member an electronic resource, etc.

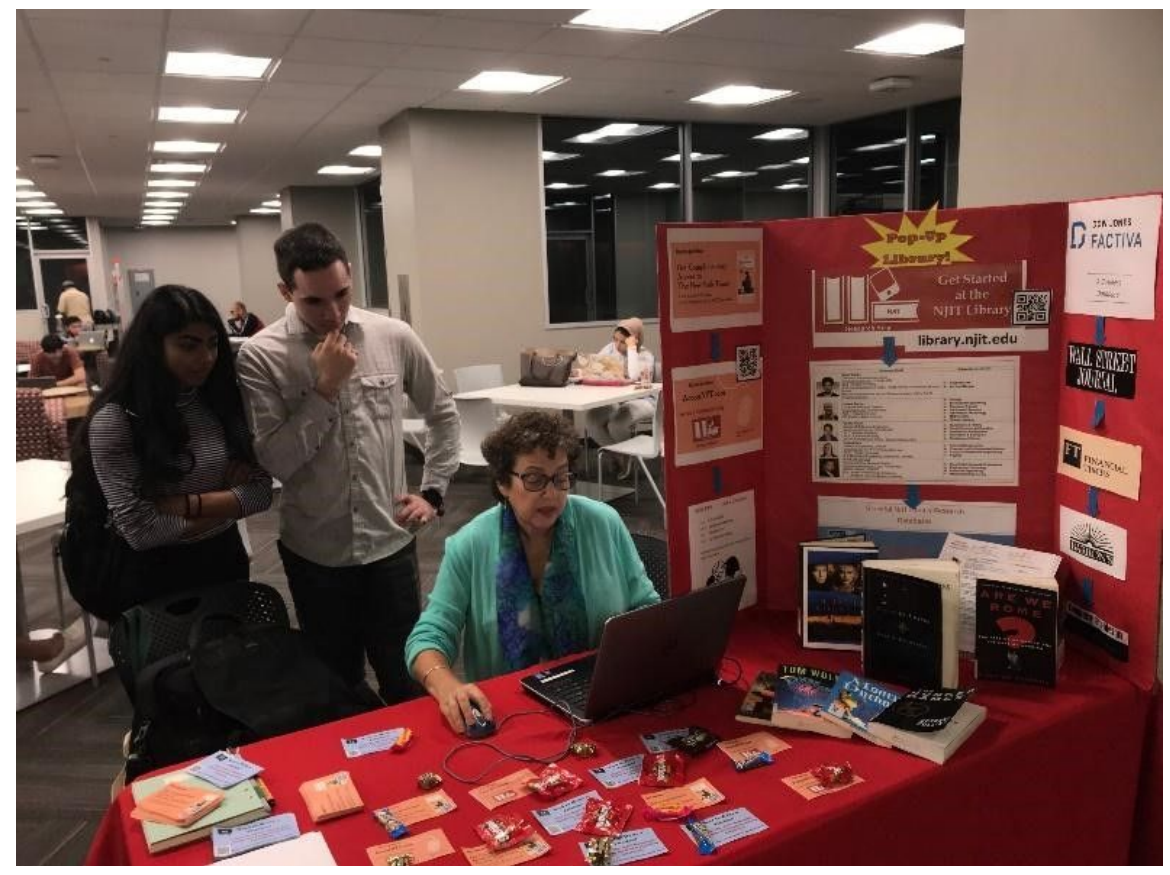

Figure 3: Pop-up in Action

\section{Results}

A total of ten pop-up libraries were conducted over the course of ten weeks. The four liaison librarians took turns facilitating the pop-ups, with two librarians at each pop-up. Eighty-two in-depth interactions or conversations with students/faculty were recorded during the pop-ups. We considered in-depth interactions to mean student/faculty initiated questions or dialog about specific library resources and services. Most of the eighty-two interactions were meaningful in the sense that some students and faculty found us at their point of need outside of the library. 
Some students needed specific assistance using the library's databases to find journal articles or help with a writing assignment. Some faculty members sought out more information about our service to create course-specific Libguides and were interested in using the liaison librarians for intervention in their classes or graduate seminars.

The largest number of in-depth interactions took place in the lobby of Tiernan Hall where the Chemistry and Environmental Science and the Chemical and Materials Engineering departments are located. In the Campus Center we were able to hand out many promotional tickets to people walking by but not many students or faculty stopped to ask questions or talk with us. Locations in other academic buildings were not as successful either. In the more social study areas of department buildings, students were busy working on projects with others and not interested in us. Quiet study areas were the same. The change over of classes appeared to be a good time to be in the department buildings, however, most students were in a hurry to or from class and didn't have time for any lengthy conversations.

\begin{tabular}{|l|c|c|c|}
\hline \multicolumn{1}{|c|}{ Pop-Up Location } & Time & $\begin{array}{c}\text { Interactions/ } \\
\text { Conversations }\end{array}$ & $\begin{array}{c}\text { Promotional Tickets } \\
\text { Distributed }\end{array}$ \\
\hline Campus Center Atrium & $12: 00 \mathrm{pm}-2: 30 \mathrm{pm}$ & 15 & 120 \\
\hline Library Building Lobby & $11: 00 \mathrm{am}-12: 00 \mathrm{pm}$ & 15 & 104 \\
\hline Campus Center Main Hall & $12: 00 \mathrm{pm}-1: 00 \mathrm{pm}$ & 8 & 10 \\
\hline $\begin{array}{l}\text { Central King Bldg. Quiet } \\
\text { study space }\end{array}$ & $11: 30 \mathrm{am}-11: 45 \mathrm{am}$ & 2 & 8 \\
\hline $\begin{array}{l}\text { Tiernan Hall - Chem \& } \\
\text { Chem. Eng. Department } \\
\text { Building }\end{array}$ & $1: 00 \mathrm{pm}-2: 00 \mathrm{pm}$ & 20 & 30 \\
\hline Campus Center Main Hall & $2: 00 \mathrm{pm}-3: 00 \mathrm{pm}$ & 3 & 60 \\
\hline $\begin{array}{l}\text { Campus Center Main Hall } \\
\text { Kupfrian Hall - Social study } \\
\text { space }\end{array}$ & $2: 20 \mathrm{pm}-3: 00 \mathrm{pm}$ & 5 & 60 \\
\hline $\begin{array}{l}\text { GITC Lobby - Mech. Eng. \& } \\
\text { Comp. Sci. Department } \\
\text { Building }\end{array}$ & $11: 00 \mathrm{am}-12: 00 \mathrm{pm}$ & 3 & 9 \\
\hline Kupfrian Hall - Social study & $2: 30 \mathrm{pm}-3: 30 \mathrm{pm}$ & 6 & 5 \\
\hline Table 1: Pop-Up Resuls & 5 & 5 & \\
\hline
\end{tabular}

Table 1: Pop-Up Results 
More than 500 promotional tickets were handed out during the pop-ups promoting several different e-resources and library services. One of the e-resources we wanted to promote extensively was the free subscription to the New York Times online newspaper. With our close proximity to New York City and the newspaper's access limited to only 3 free articles per month for an unsubscribed user, we had hoped that this resource would be beneficial for our students and faculty. So, a large number of promotional tickets which publicized the free access to the newspaper and the Libguide on how to register for an account were handed out at our pop-ups throughout September and October. Usage data from that time period showed that we did not generate a significant amount of new accounts over the number of new accounts created the previous year without the pop-up marketing. However, statistical data from Springshare LibApps software showed that usage of the New York Times LibGuide increased by $70 \%$ from the same period the previous year. This seemed counterintuitive, but we surmised that two scenarios might have been in play. First, each subscription needs to be renewed annually, therefore the number of accounts that were created the previous year may not have been all been renewed. Two, we also know that more classes were requiring the use of the New York Times as a resource for assignments, which would attribute to increased usage of the LibGuide and maybe just enough new accounts to counterbalance those that didn't renew. Therefore, the total new accounts did not significantly increase. It is difficult to ascertain whether our efforts with the pop-ups proved fruitful in this regard.

We also handed out promotional tickets for LibGuides for specific science and engineering discipline databases and how to write correct citations. Statistical data from Springshare LibApps software for the Understanding Citations LibGuide decreased by $14 \%$ from the same period the previous year. The slight decrease is mostly likely due to students preferring to use the internet and/or internet citation generators to find the correct way to cite sources in their assignments instead of using this other resource. The other LibGuides that were promoted resulted in comparable statistics to the same period the previous year.

\section{Conclusions}

The use of the pop-up library concept provided us with mixed results. The two primary goals were to increase the library's visibility and to promote specific resources and services to primarily science and engineering students who may not use the physical or virtual library space.

Based on the quantitative results and on our liaison librarians' interpretations, the pop-ups were successful in increasing the library's visibility to more students. Connecting our faces to the library's resources and services was beneficial. The pop-ups also provided a serendipitous value to students and faculty. Many that stopped to talk with us said they' $\mathrm{d}$ been meaning to come to 
the library to talk with us or ask questions, so we encountered many of them at their time of need for assistance or to exchange ideas of future collaboration that otherwise may not have taken place.

The negative aspects of the pop-up library concept were mainly due to time constraints and in difficulty determining the best places and times to pop-up. The schedule of a liaison librarian is constantly in-flux. As we are a small group of four librarians, our schedules vary day-to-day based on our department's instructional schedule and our coverage of the reference desk. There were many times when we would schedule a pop-up but other matters would require our attention so that we couldn't leave the library. In addition, determining the best places and times to do the pop-ups proved difficult. Students are usually in a hurry to or from class in department buildings, don't want to be bothered in quiet study areas in department buildings, and not interested in the bustling campus center, which is more of a social / dining area. It needs to be timed when there is the maximum amount of students with the maximum amount of downtime or at their point of need when working on an assignment, which is difficult when class schedules differ throughout each day.

\section{Where do we go from here?}

As we reassess the viability of continuing the library pop-up program the following are points that need further consideration.

1) We need to conduct more upfront observation to determine the best places and the best times for us to conduct a pop-up. More surveillance of student activity at different times, days, and locations would be helpful and conducting an informal survey of students that use the library to see where they think it would be beneficial for us to appear. It may also be beneficial to have a more consistent schedule so that students/faculty begin to expect us to be in a certain location at a certain time.

2) The librarians need identification. Most of the time when we approached students during the pop-ups they didn't know we were from the library and were confused by what we were doing. Wearing identifying buttons or name tags should be considered.

3) Publicizing the pop-ups beforehand should be considered. For this initial program we decided to pop-up unannounced at each location for more serendipitous encounters. However, in the future it may help with visibility if we promote the program on our website, in the student newspaper or in a library newsletter.

As we strive to engage more science and engineering students/faculty in the use of our physical and virtual library spaces, getting out on campus in as many ways as possible is the key to increasing the library's visibility and usefulness to all students and faculty. This will, in turn, 
create more opportunities for the NJIT community to know where to go for their information literacy needs. Although there were mixed results in our initial pop-up library program, it may prove worthwhile to continue to experiment with this method next semester.

\section{References}

[1] ABET Criteria for Accrediting Engineering Programs, 2018-2019 [Online] https://www.abet.org/accreditation/accreditation-criteria/criteria-for-accrediting-engineerin g-programs-2018-2019/ [Accessed November 29, 2018].

[2] B.P. Chang, H.N. Eskridge, "What engineers want: lessons learned from five years of studying engineering library users," in 122nd ASEE Annual Conference \& Exposition, June 14-17, 2015.

[3] D. Zwicky, "Work-in progress: "ask us here" in the shadow of hunt library," in 120th ASEE Annual Conference \& Exposition, June 23-26, 2013.

[4] A.J. Carroll, B.P. Change, H.N. Eskridge, "Lab-integrated librarians: engagement with unreachable researchers," in 124th ASEE Annual Conference \& Exposition, June 25-28, 2017.

[5] M. Gross, D. Latham, "Attaining information literacy: an investigation of the relationship between skill level, self-estimates of skill and library anxiety," Library \& Information Science Research, vol. 29, p. 332-353, 2007.

[6] J. Fransen, "How do engineering students and faculty use library resources?" in 120th ASEE Annual Conference \& Exposition, June 23-26, 2013.

[7] H. Empey, N. Black, "Marketing the academic library," College \& Undergraduate Libraries, vol. 12, no. 1-2, p. 19-33, 2005.

[8] A. Thorpe, H. Bowman, "Promoting discovery: Creating an in-depth library marketing campaign,” Journal of Library Administration, vol. 53, no. 2-3, p. 100-121, 2013.

[9] A. Davis, C. Rice, D. Spagnolo, J. Struck, S. Bull, "Exploring pop-up libraries in practice," The Australian Library Journal, vol. 64, no. 2, p. 94-104, 2015. 
[10] J. Barnett, S. Bull, H. Cooper, "Pop-up library at the university of birmingham: extending the reach of an academic library by taking 'the library' to the students," New Review of Academic Librarianship, vol. 22, no. 2 / 3, p. 112-131, Apr-Sep 2016.

[11] S. Hines, "Outpost reference: meeting patrons on their own ground," PNLA Quarterly, vol. 72, no. 1, p. 12-26, 2007.

[12] D. Del Bosque, K. Chapman, "Your place or mine? Face-to-face reference services across campus," New Library world. vol. 108, no. 5 / 6, p. 247-262, 2007.

[13] C.L. Blevens, V. K. Muyumba, "Where the old meets the new: what does the next generation really expect from librarians?" in 17th Annual Brick \& Click Academic Library Conference, November 3, 2017.

[14] M. Strothmann, K. Antell, "The live-in librarian: developing library outreach to the residence halls," Reference \& User Services Quarterly, vol. 50, no. 1, p. 48-58, 2010. 